\title{
ANALISIS PENGGUNAAN SOREKARA, SOSHITE, DAN SORENI DALAM WEBSITE SURAT KABAR ASAHI.COM
}

\section{Rudi Hartono Manurung}

\author{
Japanese Department, Faculty of Humanities, Bina Nusantara University \\ Jln. Kemanggisan Ilir III No. 45, Kemanggisan - Palmerah, Jakarta 11480 \\ rmanurung@binus.edu
}

\begin{abstract}
Setsuzokujoshi is a particle that shows the relationship between sentences, as well as having an important role in sentences. What characterizes setsuzokujoshi is its position which is always located between two sentences. Setsuzokujoshi, which is part of particles in Japanese, has many types. In this study, the researcher will limit the research on the use of れから，そして，それに contained in the newspaper articles of asahi.com website. The research method used is descriptive and library methods. This study intends to determine the function of setsuzokujoshi それ から，そして，そ れに and whether it can replace each other in a sentence and that Japanese language learners can determine the apparent similarities and differences between sorekara, soshite, and soreni, so that Japanese language learners can use them correctly. After analyzing the data, it is found that some conclusions namelyそして is used to strengthen problems of a topic of conversation because there is awareness of the speaker. It is often used when combining a topic of conversation. While それ から is reinforcing actions in sequence-based. That is, there will be a second activity to be performed or occurring after the first activity is completed. それに has a function to add anything else to a case. Because れれから has functions similar to そして, there is a possibility for そして to be replaced by それ から or vice versa.
\end{abstract}

Keywords: setsuzokushi, sorekara, soshite

\begin{abstract}
ABSTRAK
Setsuzokujoshi merupakan partikel yang menunjukkan hubungan kalimat dengan kalimat, serta mempunyai peran yang penting di dalam kalimat. Yang menjadi ciri khas setsuzokujoshi adalah posisinya yang selalu terletak di antara dua kalimat. setsuzokujoshi yang merupakan bagian dari partikel, dalam bahasa Jepang, memiliki banyak jenis. Pada penelitian ini, peneliti akan membatasai penelitian pada penggunaan それから、そして、それに yang terdapat di dalam artikel artikel website surat kabar asahi.com. Adapun metode penelitian yang digunakan adalah metode deskriptif dan metode kepustakaan. Penelitian ini bermaksud untuk mengetahui fungsi dari setsuzokujoshi それから、そして、それ にdan apakah dapat saling menggantikan dalam sebuah kalimat dan bertujuan agar para pembelajar bahasa Jepang dapat mengetahui persamaan dan perbedaan yang jelas antara sorekara, soshite, dan soreni, sehingga pembelajar bahasa Jepang dapat menggunakannya dengan baik dan benar. Setelah menganalisis data, penulis menemukan beberapa simpulan yaituそしてadalah penguatan masalah dari sebuah topik pembicaraan karena ada kesadaran dari pembicara. Sering digunakan ketika menggabungkan sebuah topik pembicaraan. Sedangkanそれからadalah tindakan menguatkan jenis secara berurutan. Artinya, akan ada kegiatan kedua yang akan dilakukan atau terjadi setelah kegiatan pertama selesai dilakukan. それにmemiliki fungsi menambahkan hal lain kepada sebuah hal. Karena それから memiliki fungsi yang hampir sama dengan そして, ada kemungkinan そしてdapat digantikan oleh それから atau sebaliknya.
\end{abstract}

Kata kunci: setsuzokushi, sorekara, soshite 


\section{PENDAHULUAN}

Ketika mempelajari bahasa Jepang, seorang pasti akan berhadapan dengan partikel. Partikel memiliki peran yang penting dalam membentuk suatu kalimat dan membuat arti dari kalimat tersebut makin jelas. Adakalanya pembelajar bahasa jepang salah dalam menggunakan partikel dalam kalimat yang diucapkannya. Secara garis besar, partikel (助詞) dalam bahasa Jepang dibagi dalam empat jenis, yaitu: kakujoshi, fukujoshi, setsuzokujoshi dan shuujoshi.

Sudrajat (2001) menyebutkan sebagai berikut. Setsuzokujoshi adalah partikel yang berfungsi untuk menghubungkan antara kata maupun kalimat. Yang termasuk dalam kata bantu setsuzokujoshi adalah: ば、と、て も、けれど、が、のに、ので、から、し、て、なが ら、たり、ものの、ところで. Setsuzokujoshi merupakan partikel yang menunjukkan hubungan kalimat dengan kalimat,serta mempunyai peran yang penting di dalam kalimat dan susunan wacana.

Ciri khas setsuzokujoshi adalah posisinya yang selalu terletak di antara dua kalimat. Setsuzokujoshi yang merupakan bagian dari partikel dalam bahasa Jepang memiliki banyak jenis. Dalam penggunaanya, ada beberapa setsuzokujoshi yang memiliki fungsi dan arti yang hampir sama, misalnya konjungsi それから、そして、 それに、また、そのうえ、それで、dan lain lain. Seperti contoh pada kalimat berikut ini.

(a) 彼女は頭がょく有の能な秘書だ。\{そして/ それから\}気立てもいい。

Kanojo wa atama ga yoku yuunouna hishoda. \{soshite/sorekara\} kidate mo ii.

Dia wanita yang pintar dan sekretaris yang berbakat. \{selain itu\} sifatnya pun baik.

(b) 連絡は以上です。…亦、 $\{0$ それから/？そ して/?それに\}次回の予定は 9 日です。

Renraku wa ijou desu. ...... \{O sorekara/soshite/ soreni\} jikai no yotei wa kokonoka desu.

Pemberitahuan dari saya cukup. ...oh iya, $\{$ lalu $\}$ rencana berikutnya tanggal 9 .

(Iori, Takanashi, Nakanishi, \& Yamada, 2001:208)

Penelitian ini bermaksud untuk mengetahui fungsi dari setsuzokujoshi それから、そして、それに. Kemudian penelitian juga ingin mengetahui apakah $₹ れ か$ ら、そして、それに dapat saling menggantikan dalam sebuah kalimat dan pada situasi atau kondisi bagaimana dapat digunakan. Sedangkan manfaat dari penelitian ini adalah agar para pembelajar bahasa Jepang dapat mengetahui persamaan dan perbedaan yang jelas antara sorekara, soshite, dan soreni, sehingga pembelajar bahasa jepang dapat menggunakannya dengan baik dan benar.

\section{METODE}

Dalam penelitian penulis menggunakan metode deskriptif dan metode kepustakaan. Metode deskriptif adalah metode dengan cara kerja membahas suatu masalah dengan menata dan mengklasifikasikan serta memberi pen- jelasan tentang gejala-gejala yang tampak pada data tanpa melakukan pengujian. Sementara yang dimaksud dengan metode kepustakaan yaitu cara pengumpulan data yang dilakukan terhadap sejumlah naskah tertulis yang merupakan korpus data. Dalam penelitian ini metode deskriptif dilakukan pada tahap penelitian data sedangkan metode kepustakaan dilakukan pada tahap pengumpulan data.

\section{Kajian Teori Sorekara, Soshite, Soreni}

Ishikawa (1978) dalam setsuzokushi soshite, sorekara, soreni, sonoue no youhou mengatakan bahwa jumlah dasar titik kalimat di bagi dalam delapan jenis klausa sebagai berikut:

市川1978の 分類(ぶんるい)によれば、 文の連接関係（れんせつかんけい）の基本的類型（き ほんてきるいけい)は八つ（順接型(じゅんせつが た）、逆接型（ぎやせつがた）、添加型（てんかが た）、対比型 (たいひかた)、転換型（てんかんがた） 、同列型 (どうれつかた)、補足型 (ほそくかた)、連 鎖型 (れんさがた) ) に分けるが、「そして」は「添 加型(てんかがた)」の「累加（るいか）、単純(たん じゅん）な添加（てんか）」に属（ぞく）し、「それか ら、それに、そのうえ」は「添加型（てんかがた）」 の「追加(ついか)」に属(ぞく)するとされている。

Terjemahan:

"Menurut klasifikasi dari Ichikawa 1978, Jumlah dasar titik kalimat dibagi dalam delapan buah yaitu jenis klausa urutan, jenis klausa paradok, jenis penambahan,jenis kontras,jenis konversi, jenis berkategori sama, jenis tambahan, jenis berantai $そ し て$ adalah jenis penambahan yang bersifat sederhana dan bersifat berulang ulang. Sedangkan それから、それに、そのうえ termasuk jenis penambahan yang bersifat menambah."

Sedangkan Morita (1989) dalam setsuzokushi soshite, sorekara, soreni, sonoue no youhou melakukan analisis terhadap empat kata dan membaginya menjadi soshite (そして)、sorekara (それから) dan soreni (それ に)、sonoue (そのうえ) kemudian “soreni/sonoue (それ に/そのうえ) sorekara (それから)” dan “soreni/sonoue (それに/そのうえ) soshite (そして)” sebagai berikut:

「そして」は事柄(ことがら)の累加意識(る いかいしき)であるから、事柄(ことがら)の二重性( にじゅうせい)が強(つょ)まるのに対(たい)して、

「それに、そのうえ」は、ある事柄(ことがら)に他 （た）の事柄(ことがら)が累加(るいか)する意(い)で あるから、「それから」に置(お)き換(か)えること も可能(かのう)であるが、「それから」は時間的 順序(じかんてきじゅんじょ)で展開(てんかい)して いく場合(ばあい)にも使用(しょう)できる。「それ に、そのうえ」は、事柄(ことがら)や話題(わだい) を累加(るいか)する説明的叙述(世つめいてきじょ じゅつ)として用(もち)いられる。接続助詞(世つぞ くじょし)「し」に通(つう)じる。これに対して、

「そして」は、一つの話題(わだい)で統一(とうい つ)されている時(とき)によく用(もち)いられ、接 続助詞(せつぞくじょし)「て」に通(つう)じる。 
Terjemahan:

“そして adalah penguatan masalah terhadap dualisme karena ada kesadaran komulatif terhadap masalah/ hal/perkara. それから adalah tindakan mengintensifkan/ menguatkan jenis secara berurutan. それに、そのうえ ada kemungkinan dapat digantikan oleh それから karena memiliki arti menambahkan hal lain kepada sebuah hal. それから dapat juga digunakan apabila mengembangkan urutan kegiatan berdasarkan waktu.それに、その j $え$ digunakan sebagai pengutaraan penjelasan dalam menambahkan hal atau tema pembicaraan. Bisa dipahami seperti「し」dalam setsuzokujoshi . Berbeda dengan hal ini, そして sering digunakan ketika menyatukan sebuah topik pembicaraan. Bisa pula dipahami seperti $\lceil\tau\rfloor$ dalam setsuzokujoshi."

\section{HASIL DAN PEMBAHASAN}

Berdasarkan analisis yang telah dilakukan terhadap kalimat-kalimat yang mengandung sorekara, soshite, soreni「それから，そして，それに」 yang terdapat dalam artikel pada surat kabar Asahi Shinbun dengan menggunakan teori Ishikawa dan Morita dan teori-teori pendukung lainnya, penelitian menemukan fungsi-fungsi sebagai berikut:

Analisis Fungsi setsuzokushi sorekara「それから」 yang Menunjukkan Pengembangan Urutan Kegiatan Berdasarkan Waktu

Data 1

僕（ぼく）たちの目標（もくひょう）は試合（し あい)に勝(か)つことだ。それから、シーズンの終( お)わりにどうなっているかを見(み)るよ。ただ、 最後(さいご) に勝 (か)つてから、かなり時間 (じか ん)が経(た)つているね。

\section{Terjemahan}

Tujuan kami adalah memenangkan pertandingan. Kemudian kita akan lihat kondisi di akhir musim nanti akan seperti apa. Hanya saja karena kami menang di penghujung waktu pertandingan, berjalannya waktu terasa lumayan lama.

\section{Analisis}

Dari kalimat artikel tersebut, dapat dilihat bahwa ada dua hal yang disampaikan pada artikel tersebut. Pertama mereka ingin memenangkan setiap pertandingan.kemudian pada bagian kedua mereka akan melihat kondisi akhir musim untuk menentukan langkah berikutnya. Pada artikel setelah kalimat pertama selesai dilanjutkan dengan kataそれから. Dengan dimasukkannya それから untuk menghubungkan kedua hal ini maka それからyang seperti ini berfungsi untuk menunjukkan pengembangan urutan kegiatan berdasarkan waktu. Urutan kegiatan berdasarkan waktu pada artikel dapat dilihat pada mereka ingin menyelesaikan pertandingan (kegiatan pertama) baru kemudian memikirkan akhir musim liga (kegitan kedua yang ingin mereka gapai setelah kegiatan pertama dilakukan). Dengan melihat hal ini makin jelas fungsi それから yang menunjukkan pengembangan urutan kegiatan berdasarkan waktu. Hal ini juga didukung dengan teori Iori yang mengatakan それから berfungsi untuk mengurutkan atau menambahkan hal atau kegiatan.

Bagan pembuktian penggunaan Setsuzokushi pada Setsuzokushi sorekara「それから」dalam data dapat dilihat sebagai berikut.

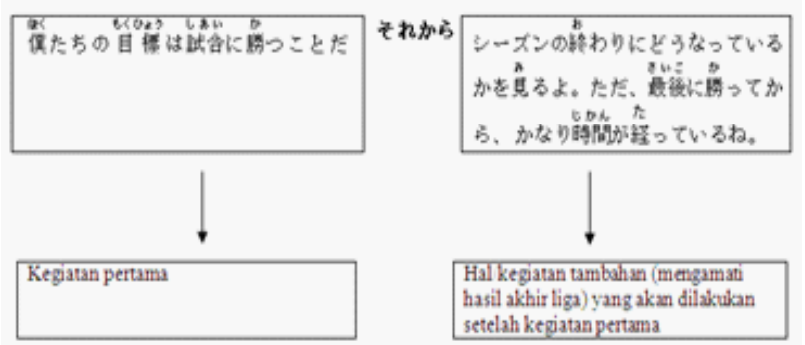

Data 2

F A カップは常(つね)に難(むずか)しいもの だと思(おも)つている。レス夕一は最初(さいしょ) の 20 分間(ふんかん)で良(よ)いプレ一をしたが、 それから我々(われわれ)のプレ一が良(よ)くなっ た。

\section{Terjemahan}

Seperti biasa FA Cup adalah hal yang sulit untuk dicapai. Pada 20 menit awal pertandingan,pemain bermain baik. Kemudian permainan mereka semakin lebih baik lagi

\section{Analisis}

Dalam kutipan percakapan diatas terlihat bahwa mereka mengatakan bahwa FA Cup adalah sebuah pertandingan yang sulit untuk dimenangkan. Pada awal awal pertandingan para pemain bermain baik. Setelah kalimat ini selesai dilanjutkan dengan それから。それから di sini berfungsi untuk menunjukkan pengembangan urutan kegiatan berdasarkan waktu. Urutan kegiatan berdasarkan waktu pada artikel dapat dilihat pada kalimat pertama yang mengatakan pertandingan dimenit awal yang berjalan baik (kegiatan pertama) kemudian permainan makin baik (kegiatan kedua yang terjadi setelah kegiatan yang kedua) hal ini juga sesuai dengan Iori yang mengatakan そ れから berfungsi untuk mengurutkan atau menambahkan hal atau kegiatan.

Bagan pembuktian fungsi setsuzokushi sorekara「 それから」dalam data dapat dilihat seperti berikut.

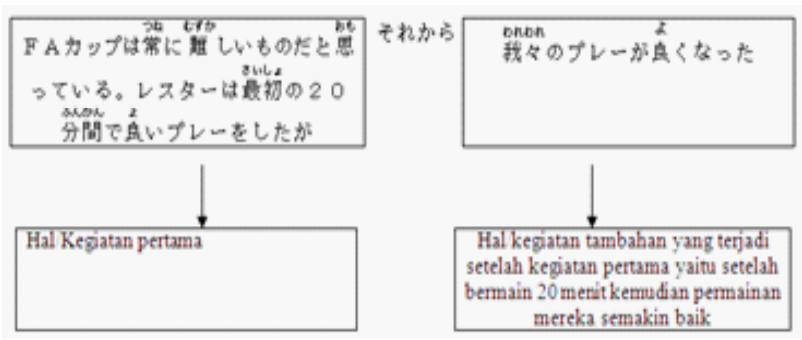

Analisis Fungsi setsuzokushi soshite $「 そ し て 」$ yang Menunjukkan Penyatuan sebuah topik pembicaraan

昭和（しょうわ）１１年（ねん）、昭和（しょう わ) 30 年代(㱛んだい)、そして現代(げんだい) と、時代(じだい)が変(か)わつても同(おな)じょう に悩(なや)み、愛(あい)し、ひたむきに生(い)きる 
女性(じょせい)たちの歩 (あゆ) みは、さらに未来 ( みらい)へとつながっていく・.

\section{Terjemahan}

Sejak tahun 11 showa, tahun Showa 30-an dan masa sekarang, meskipun jaman berganti,sama seperti sebelumnya, kesulitan, cinta yang mewarnai perjalanan para wanita yang sungguh-sungguh dalam hidupnya adalah semakin menghubungkan mereka dengan masa depan.

\section{Analisis}

Artikel bercerita tentang kondisi wanita dari jaman ke zaman. Dimulai dari tahun 11 Showa ke masa 30 Showa kemudian masa sekarang. Di sini terlihat jelas bahwa topiknya adalah masa atau zaman tentang keberadaan wanita. Meskipun terjadi pada zaman yang berbeda, pada umumnya kondisi para wanita ini tidaklah berbeda, maka penulis artikel ini mencoba menggabungkan zaman yang berbeda beda ini menjadi satu topik. Meskipun berbeda beda, temanya sama yaitu zaman, penulis artikel ini mencoba menggabungkan topik tersebut menjadi satu kesatuan dengan menggunakan kata soshite yang artinya "dan" sehingga topik ini menjadi satu kesatuan. Fungsi そし $\tau$ ini juga didukung oleh pernyataan Iori yang menyatakan bahwa salah satu fungsinya adalah menggabungkan sebuah topik pembicaraan. Pembuktian Fungsi Setsuzokushi soshite $「 そ し て 」$ dalam data dapat dilihat pada bagan berikut.

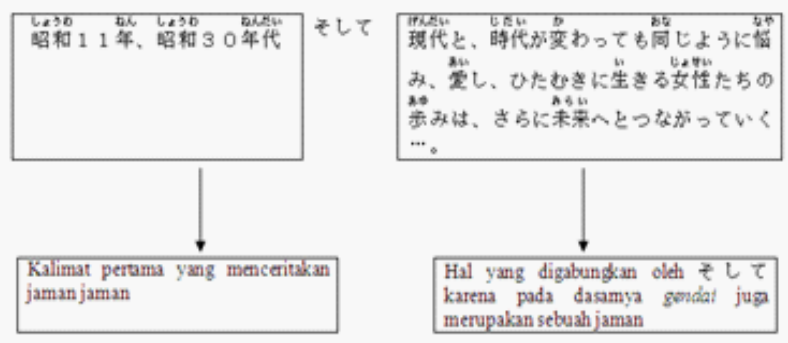

次(つぎ)に成功(せいこう)したのはそれから 1 週間(しゅうかん)たつていたが、数（すう）日（に ち)で成功(せいこう)率(りつ)は9割(わり)にまで 上(あ)がっていた。そして迎(むか)えた本番(ほん ばん)。高(たか)い成功（せいこう）率（りつ）でも不 安(ふあん)はあった。

\section{Terjemahan}

Berikutnya adalah waktu yang telah berjalan seminggu setelah sukses, tetapi beberapa hari kemudian taraf kesuksesan telah meningkat menjadi 90\%. Kemudian bersiap menghadapi pertandingan sesungguhnya. Meskipun dengan taraf kesuksesan kami di level yang sangat tinggi, rasa khawatir itu masih ada pada diri kami.

\section{Analisis}

Dalam artikel tersebut tim sepak bola yang akan bertanding sudah mempersiapkan diri melalui latihan yang serius. Akan tetapi, mereka tetap merasa khawatir terhadap pertandingan yang sesungguhnya. Hal itu ditunjukkan dengan penggunaan kata“ “成功(せいこう)率( りつ)でも不安(ふあん)はあった”. Meskipun masih ada rasa khawatir sebenarnya mereka sudah ber- siap menghadapi pertandingan sebenarnya. Mereka sudah bersiap karena taraf kesuksesan persiapan mereka sudah $90 \%$. Setelah persiapan adalah menghadapi pertandingan. Karena persiapan dan pertandingan adalah satu tema topik yang sama maka そして berfungsi untuk menyatukan tema tersebut. Fungsi そして yang seperti ini juga didukung oleh pernyataan Iori yang menyatakan bahwa salah satu fungsinya adalah menggabungkan sebuah topik pembicaraan. Pembuktian fungsi setsuzokushi soshite 「そし $\tau\rfloor$ dalam data dapat dilihat pada bagan berikut.

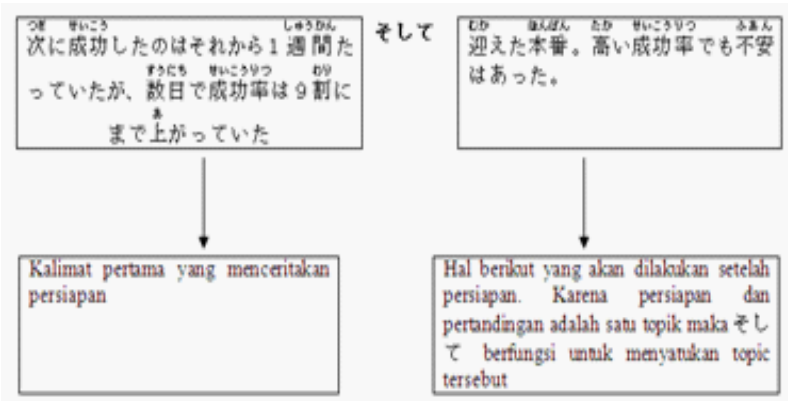

Analisis Fungsi setsuzokushi soreni 「それに」yang Menunjukkan Pengutaraan Penjelasan Dalam Menambahkan Hal atau Tema Pembicaraan

$$
\text { 本当に偉大な指揮官の一人だ」「それに、 }
$$
一緒に練習し、プレーできた、多くの素晴らしい選 手たちもいる。彼らと分かち合った経験は、生涯忘 れないよ。

\section{Terjemahan}

Dia salah satu kapten yang benar-benar hebat. Selain itu, kami berbagi pengalaman yang sama dalam latihan, bisa bermain, juga banyak pemain hebat. Dengan mereka, saya tidak akan lupa seumur hidup.

Analisis

Dalam artikel tersebut seorang pemain memuji seorang kapten tim. Ternyata selain memuji dian juga mengutarakan berbagai pengalamannya bermain bersama kapten tim tersebut dan tidak akan melupakan kenangan tersebut. Jika dilihat dari konteks, sebenarnya pemain ini pada awalnya kagum lalu dia menambahkan hal di luar pujian bahkan dia memberikan penjelasan dari hal-hal hebat yang dilakukan bersama. Untuk memperjelas dan menambahkan hal lain dari tema pembicaraannya dia menggunakan kata それに yang berfungsi untuk memberikan penjelasan dan menambahkan hal. Hal ini pun didukung oleh Iori yang mengatakan bahwa salah satu fungsi soreni adalah penjelasan dari sebuah topik pembicaraan. Pembuktian fungsi setsuzokushi soreni「それに」dalam data dapat dilihat pada bagan berikut.

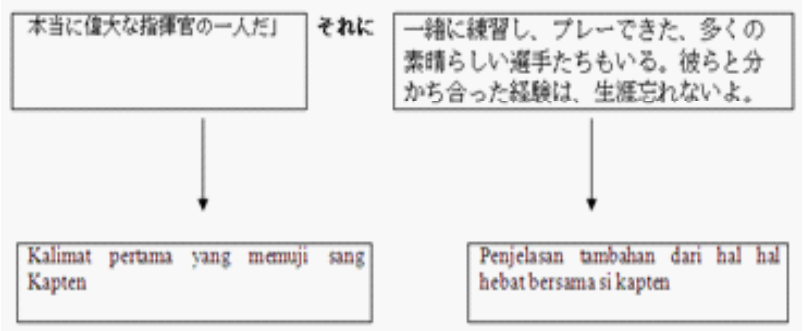


今季のビッグチーム相手の記録(きろく) は衝 撃的(しょうげきてき)なものがある。それにナポリ の高速カウンターの前には、スピードに欠ける年老 いたチェルシーは多くの問題を抱えることになる。

\section{Terjemahan}

Ada kejutan catatan rekor dari lawan tim-tim besar musim ini. Selain itu Napoli yang memiliki serangan balik berkecepatan tinggi akan menjadi masalah besar bagi Chelsea yang memiliki pemain tua dan tidak memiliki kecepatan.

\section{Analisis}

Dalam artikel tersebut dikatakan ada sebuah catatan rekor dari sebuah tim yang bernama Napoli. Ternyata Napoli ini bukan hanya memiliki catatan rekor saja tetapi juga tim yang memiliki pemain dengan kecepatan yang luar biasa dan akan membuat tim lawan harus waspada. Jika dilihat dari konteks, sebenarnya tim ini pada awalnya dikatakan hanya memiliki kecepatan saja. Namun setelah penjelasan pertama, muncul sebuah penjelasan tambahan. Untuk memperjelas dan menambahkan hal lain dari tema pembicaraannya dia menggunakan kata それに yang berfungsi untuk memberikan penjelasan dan menambahkan hal. Hal ini pun didukung oleh Iori yang mengatakan bahwa salah satu fungsi soreni adalah penjelasan dari sebuah topik pembicaraan. Pembuktian fungsi setsuzokushi soreni 「それに」 pada data dapat dilihat pada bagain berikut.
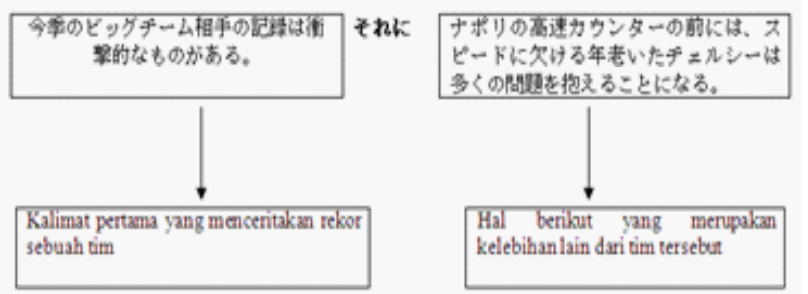

\section{SIMPULAN}

Setelah menganalisis data, penulis menemukan beberapa simpulan mengenai そしてyaitu そして adalah penguatan masalah dari sebuah topik pembicaraan karena ada kesadaran dari pembicara. そして sering digunakan ketika menyatukan atau menggabungkan sebuah topik pembicaraan. Namun ada pula fungsi lainnya yaitu menunjukkan urutan kegiatan atau peristiwa. Sedangkanそれか $ら$ adalah tindakan menguatkan jenis secara berurutan. Artinya, akan ada kegiatan kedua yang akan dilakukan atau terjadi setelah kegiatan pertama selesai dilakukan. Artinyaそれから dapat digunakan apabila mengembangkan urutan kegiatan berdasarkan waktu. それに memiliki fungsi menambahkan hal lain kepada sebuah hal. Karena それから memiliki fungsi yang hampir sama dengan そ して, ada kemungkinan そしてdapat digantikan oleh そ れから atau sebaliknya. Sedangkanそれに tidak dapat mengantikanそれから atauそしてkarena それに hanya penambahan hal atau tema lainnya terhadap hal atau tema pertama yang sifatnya penguatan saja.

\section{DAFTAR PUSTAKA}

Iori I., Takanashi S., Nakanishi K., \& Yamada T. (2001). Nihongo Bunpou Handbook. Tokyo: 3A Corporation.

Masuoka, T., \& Takubo, Y (1993). Kiso Nihongo Bunpou. Tokyo: Kuroshio Shuppan.

Sudrajat, A. (2001). Tata Bahasa Jepang Lengkap. Bandung: Pionir jaya.

Yang, X., \& Toshiomi, B. (2004). 接続詞「そして, それ から，それに，そのうえ」の用法 (On the usage of Japanese conjunctive words soshite, sorekara, soreni, sonoue). Journal of Hokkaido University of Education, Sect. Humanities and Social Science, 54(2), 27-42. 